\title{
Psychological peculiarities of the communicative culture of the teacher
}

\section{Davydova 0.*}

\author{
Kremenchuk Mikhailo Ostrogradskyi National University, Kremenchuk, Ukraine
}

Received: $20.03 .2019 \quad$ Accepted: 16.04 .2019

\begin{abstract}
The article analyzes the results of theoretical and scientific analysis of communication culture within the framework of its professional activity. Expose the structure and elements of a teacher's communicative culture through a competent approach. Characterized features of the professional communication culture of the teacher and its components, which include: knowledge, skills, abilities, motives, values and beliefs, which in general ensure the effectiveness and quality of the performance of specialists in certain activities. It was found out that a significant component of the communicative competence of the teacher is his emotional component of the culture of communication and emotional self-regulation, since professional duty requires a teacher to make informed decisions, overcome irritability, and despair. It is a question of studying the peculiarities of pedagogical culture as an integrated personality, as a dialectically integrated combination of pedagogical values: values-goals and values-motives, values-knowledge, technological values, values-properties, values-attitudes permeated with psychological content.It is noted that this phenomenon has localization in all areas of the activity of the teacher as a professional and depends on many factors. The practical-semantic field of communicative culture in the lyceum is analyzed and elucidated empirically. Statistically significant differences were established regarding the motivational indicators of social responsibility and found that they are more experienced teachers with a large work experience. The peculiarities of development of factors of communicative and social competence of teachers, their benevolence and ability to self-government in communication are analyzed. The factors that influence the culture of communication of teachers are established: sense of justice, high sensitivity, emotional reactivity and peculiarities of pedagogical motivation that are not always balanced to the optimal model.
\end{abstract}

Key words: communicative culture, pedagogical communication of teacher, communicative competence, psychological culture of communication, self-government in communication.

\section{Психологічні особливості комунікативної культури вчителя}

\author{
Давидова О. В. \\ Кременчуцький національний університет імені Михайла Остроградського, Кременчук, Україна
}

\begin{abstract}
Анотація. У статті проаналізовано результати теоретичного й емпіричного аналізу комунікативної культури вчителя в рамках його професійної діяльності. Розглянуто структуру та компоненти комунікативної культури вчителя через компетентнісний підхід. Охарактеризовано особливості профресійної культури спілкування вчителя та її складових, що уключають: знання, навички, здібності, мотиви, цінності та переконання, які в цілому забезпечують ефрективне та якісне виконання фахівцем певної діяльності. З'ясовано, що вагомою складовою комунікативної компетентності педагога є його емоційна складова культури спілкування та емоційної саморегуляції, оскільки, профресійний обов'язок вимагає від учителя приймати зважені рішення, долати дратівливість, відчай. Йдеться про вивчення особливостей педагогічної культури як інтегрованої властивості особистості, як діалектично інтегрованого поєднання педагогічних цінностей: цінностей-цілей $\mathrm{i}$ цінностей-мотивів, цінностей-знань, технологічних цінностей, цінностей-властивостей, цінностейвідношень,що пронизані психологічним змістом. Зазначено, що цей феномен має локалізацію в усіх царинах діяльності вчителя як професіонала і залежить від багатьох чинників. Емпіричним шляхом проаналізовано та висвітлено практично-смислове поле комунікативної культури в ліцеї. Встановлено статистично значущі відмінності стосовно мотиваційних показників соціальної відповідальності й виявлено, що вони притаманні більш досвідченим педагогам з більшим трудовим стажем. Проаналізовано особливості розвиненості факторів комунікативної та соціальної компетентності учителів, їх доброзичливості та здатності до
\end{abstract}

\footnotetext{
Corresponding Author: Davydova Oksana Volodymyrivna. Phone: 067-90-100-46. E-mail: 71kseniya@gmail.com Kremenchuk Mykhailo Ostrohradskyi National University, vul. Pershotravneva, 20, Kremenchuk, Poltava Region, Ukraine, 39600.

Відповідальний автор: Давидова Оксана Володимирівна. Тел. 067-90-100-46. E-mail: 71kseniya@gmail.com Кременчуцький національний університет імені Михайла Остроградського, вул. Першотравнева, 20, м. Кременчук Полтавської обл., Україна, 39600.
} 
самоуправління в спілкуванні. Встановлено фактори, які впливають на культуру спілкування вчителів: почуття справедливості, висока сензитивність, емоційна реактивність та особливості педагогічної мотивації, які не завжди збалансовані до оптимальної моделі.

Ключові слова: комунікативна культура, педагогічна комунікація вчителя, комунікативна компетентність, психологічна культура спілкування, самоуправляння в спілкуванні

\title{
Психологические особенности коммуникативной культуры учителя
}

\author{
Давыдова О. В.
}

Кременчугский национальный университет имени Михаила Остроградского, Кременчуг, Украина

\begin{abstract}
Аннотация. В статье проанализированы результаты теоретического и эмпирического анализа коммуникативной культуры учителя в рамках его профессиональной деятельности. Представлена структура и компоненты коммуникативной культуры учителя с помощью компетентностного подхода. Охарактеризованы особенности профессиональной культуры общения учителя и ее составляющих: знания, навыки, способности, мотивы, ценности и убеждения, которые в целом обеспечивают эффективное и качественное выполнение специалистом определенной деятельности. Выяснено, что важной составляющей коммуникативной компетентности педагога является его эмоциональная культура общения и эмоциональная саморегуляции, поскольку профессиональный долг требует от учителя принимать взвешенные решения, преодолевать раздражительность, отчаяние. Речь идет об изучении особенностей педагогической культуры как интегрированного свойства личности, как диалектически интегрированного сочетания педагогических ценностей: ценностей-целей и ценностей-мотивов, ценностей-знаний, технологических ценностей, ценностейсвойств, ценностей-отношений, которые переплетены психологическим содержанием. Отмечено, что этот феномен имеет локализацию во всех сферах деятельности учителя как профессионала и зависит от многих факторов. Эмпирическим путем проанализированы и освещены особенности практически-смысловоого поля коммуникативной культуры в лицее. Установлено статистически значимые различия в отношении мотивационных показателей социальной ответственности и обнаружено, что они присущи более опытным педагогам с большим трудовым стажем. Проанализированы особенности развитости факторов коммуникативной и социальной компетентности учителей, их доброжелательности и способности к самоуправлению в общении. Установлены факторы, которые влияют на культуру общения учителей: чувство справедливости, высокая сензитивность, эмоциональная реактивность и особенности педагогической мотивации, которые не всегда сбалансированы в соответствии с оптимальной моделью.

Ключевые слова: коммуникативная культура, педагогическая коммуникация учителя, коммуникативная компетентность, психологическая культура общения, самоуправляння в общении.
\end{abstract}

\section{Bcmyn}

В умовах глибоких соціально-економічних перетворень і трансформаційного сценарію розвитку системи освіти України, зорієнтованої на європейський вимір, розширюється діапазон нових освітніх компетенцій учителів, зокрема їх комунікативної культури. До того ж формуються нові ідеологія та практика життєдіяльності сучасної школи як соціально-педагогічної системи, результатом якої $\epsilon$ розвиток в учнів «вмінь визначати навчальні цілі та способи їх досягнення, вибудовувати свою навчальну траєкторію, оцінювати власні результати навчання, навчатися впродовж життя» [1].

У даний час освітня установа, іноді виступає стресогенним фактором, причиною якого є низький рівень комунікативної культури педагога і як результат нездатність до нових комунікативних форм взаємодії з учнями та їх батьками. Це об'єктивна реальність, і на наш погляд, сучасна школа не може нею нехтувати.

Підкреслюючи роль школи в духовному розвитку школярів, не можна не відзначити гостру необхідність підвищення культурного рівня вчителів, у тому числі й керівників навчальних закладів, які сьогодні не завжди відповідають/хочуть відповідати сучасним освітнім вимогам, утримуючи гасла традиційної педагогіки. Останнє вказує на наявність опорів стосовно нововведень і $є$ поширеним явищем сьогодення.

Необхідність професійної переорієнтації обумовлена тим, що вчитель постійно включений в процес спілкування, який передбачає багатовекторні відносини з партнерами по контакту: учнями, батьками, колегами.

Методологічною підставою трансфрормаційної позиції педагога $€$ ідеї НУШ (Нової української школи) в освіті. Це, в свою чергу, підводить до усвідомлення й необхідності нового рівня комунікативної 
культури вчителя, що проявляється готовності до інших форм спілкування та співпраці, в уявленнях про іншу людину як цінності, в готовності прийняти точку зору іншого, у витримці, такті при розв'язання конфрліктів.

Саме комунікативна діяльність педагога $є$ основним засобом вирішення педагогічних завдань. У цьому зв'язку, питання комунікативної культури є актуальними, оскільки зразки поведінки, що задаються підростаючим поколінням, повинні транслюати високі орієнтири педагогічної культури нових прийнятих форм спілкування, наближати їх до найсучасніших еталонів духовності та обумовлювати конструктивними психолого-педагогічними впливами.

\section{II Матеріал і методи дослідження}

Теоретичні розвідки з проблеми комунікативної культури показують, що феномен «комунікативна культура» часто ототожнюється 3 поняттями: «культура спілкування» (І. Ільяєва, Е. Макарян), «комунікативна компетентність» (С.Л.Братченко, Ю.. Емельянова, Е. Руденскій), «комунікативна компетенція» (М. Вятютнев), "культура мови» (Л. Введенская, Л. Павлова, Б. Головін), «культура мовного спілкування» (О. Казарцева), «культура мовної поведінки» (А. Міхальская). Багатозначність самого поняття «культура» відбивається в неоднозначності тлумачення змісту різних їі словосполучень, у тому числі: «управлінська культура керівника», «культура управлінської діяльності», «культура управління».

Поняття «професійна культура особистості» порівняно нове в педагогіці. Відомо, що в середині XX ст В.Сухомлинський сміливо ввів у педагогічний обіг феномен «культура», який склав культурологічного тезаурусу в його педагогічній спадщині, зокрема: інтелектуальна культура, моральнодуховна культура, культура праці, культура почуттів, культура мислення, культура сприймання, культура відчуттів, культура волі та ін.

Термін "культура спілкування" в Україні з'явився у 80-х роках минулого століття та введено в науку психологом Т. Чмут [2].

Дослідженням профресійного спілкування, його структурою та впливами на дітей займався КанКалик. Вчений виокремив 4 етапи комунікації в структурі педагогічної взаємодії [3, с.27], а також показав різноманіття професійних сценаріїв педагога, виділяючи найбільш бажані /небажані моделі поведінки.

Л.Хомич акцентує увагу на тому, що професійна культура фахівця базується на здатності до розвитку, можливостях вдосконалювати свої творчі можливості при розв'язках нестандартних завдань [4, c. 21].

Комунікативна культура може бути розглянута в рамках компетентнісного підходу, запропонованого В. Янушевським, як здатність особистості отримувати через діалог та в публічному виступі необхідну інфрормацію про співрозмовника (рівні його освіченості, вихованості, характер і особливості його комунікативної культури і т.д); визнання різноманітності позицій і шанобливого ставлення до цінностей (релігійних, етнічних, професійним, особистісним і т.п.) інших людей. Суть цього підходу полягає у виділенні декількох ключових компетенцій, на основі яких і здійснюється формування цілісної картини комунікативної культури, що є синонімом педагогічного професіоналізму.

Для прикладу, Г. Селевко виділяє 7 ключових «суперкомпетентностей», серед яких виокремлює комунікативну та інформаційну. Перша визначається як уміння вступати в комунікацію, друга як уміння володіти інформаційними технологіями, працювати з усіма видами інформації [5]. В цьому контексті, О. Бондарчук підкреслює, що потенціальними складовими компетентності є знання, навички, здібності, мотиви, цінності та переконання,які в цілому забезпечують ефективне та якісне виконання нею певної діяльності [6].

В цьому контексті психологічної культури спілкування включають наступні компоненти: 1. Психологічні знання як основа не тільки психологічної, а й професійної культури вчителя. 2. Психологічну готовність до вчительської праці, яка пов'язана з усвідомленням її соціального значення. 3. Особистісні якості вчителя/педагогічні здібності. 4. Емоційно-вольову сферу особистості педагога, яка забезпечує здатність свідомо керувати своїми емоціями, регулювати свої дії і поведінку, володіти собою, створювати позитивний емоційний настрій і сприятливий психологічний клімат. 5. Характерологічні й типологічні властивості педагога і прямо чи опосередковано впливають на 
успішність навчальної діяльності чи на характер стосунків з учнями, колегами, батьками. 6. Прагнення й здатність особистості педагога постійно вдосконалюватися, займатися самоосвітою/саморозвиток [7].

Виходячи з поперднього, вагомою складовою комунікативної компетентності педагога $є$ його емоційна складова культури спілкування та емоційної саморегуляції, оскільки, професійний обов'язок вимагає від учителя приймати зважені рішення, долати дратівливість, відчай. Ці психологічні навантаження, одержувані вчителем, призводять до розвитку у нього професійного стресу. В цьому сенсі, стануть в пригоді психологічні практики з попередження та подолання стресової симптоматики.

у цьому зв'язку, будемо притримуватись логіки стосовно поняття комунікативної культури вчителеля як системи внутрішніх ресурсів, необхідних для ефективної педагогічної комунікації.

Таким чином, теоретичні розвідки стосовно поняття «педагогічної культури» дають змогу говорити про неодностайність існуючих поглядів та наявність різноманітних підходів, що не дозволяє виокремити єдине, «універсальне» пояснення сутності цього феномену. Наголосимо, що йдеться про вивчення особливостей педагогічної культури як інтегрованої властивості особистості, включає психологічний зміст. Безумовно, вчитель має бути носієм високої загальнолюдської культури, що визначається, насамперед, справжньою інтелектуальністю та високою духовністю, широким світоглядом, глибокою ерудицією, а також повинен мати справжні поняття про честь, совість, громадську мужність, уміти володіти собою в будь-якій, навіть екстремальній ситуації. Педагогічна культура вчителя розглядається як діалектична інтегрована єдність педагогічних цінностей: цінностей-цілей і цінностей-мотивів, цінностей-знань, технологічних цінностей, цінностей-властивостей, цінностей-відношень. Вони є новими осями координат, що визначають модель педагогічної культури, спрямовують і коригують у соціальному, духовному, професійному й особистісному просторі діяльність учителя. Посилена увага до розвитку індивідуально-ділового потенціалу вчителя: гнучкості, мобільності, пошукової активності, комунікативної культури, готовності до самопізнання, саморозвитку, самоактуалізації.

\section{III Результати}

Для розв'язання емпіричних завдань було використано діагностичний інструментарій: опитувальник «Діагностика комунікативної та соціальної компетентності КСК» М.П.Фетіскін, В.В.Козлов, Г.М. Мануйлов; методика вивчення здатності до самоуправління в спілкуванні» М. П. Фетіскін, В.В.Козлов, Г. М. Мануйлов; методика «Дослідження мотивації професійної діяльності і педагогічних працівників (О. І. Бондарчук, Л. М. Карамушка)»; Шкала Кемпбелла щодо визначення доброзичливості.

Експериментальна база дослідження - Кременчуцький ліцей № 30 «Олімп» імені Н. М. Шевченко. Загальний обсяг вибірки - 36 вчителів предметників. Виходячи з ресурсу навчального закладу, всі особи жіночої статі, віком від 21-до 65 років, які склали три групи досліджуваних за показниками стажу. А саме, в першу групу ввійшли педагоги, що працюють в ліцеї від 1 -до 5 років. Другу групу - склали педагоги, які мають стаж роботи в закладі від 6-15 років. Відповідно, в третю досліджувану групу ввійшли педагоги, які працюють в закладі освіти більше 16 років. Групи сформовано в кількості по 12 осіб кожна.

За результатами емпіричного дослідження за методикою «Дослідження мотивації професійної діяльності і педагогічних працівників (О. І. Бондарчук, Л. М. Карамушка)» констатовано: мотиви зробити кар'єру, досягти визнання та здобувати авторитет не є домінуючими для більшості респондентів, навіть за умови стійкої тенденції до особистісного зростання та виразності власне професійних мотивів. Встановлено статистично значущі відмінності за допомогою Т-критерію $(p<0,01)$ стосовно мотиваційних показників соціальної відповідальності й виявлено, що вони притаманні більш досвідченим педагогам,тобто тим, в кого з більший трудовий стаж.

Наступним кроком включимо до аналізу результати діагностики за опитувальником комунікативної та соціальної компетентності КСК (М. П. Фетіскін, В. В. Козлов, Г. М. Мануйлов) представлено в діаграмі (рис. 1). Де фактори:

А - відкритість/замкненість;

В - логічне мислення/

C - емоційна стабільність/мінливість;

D - життєрадісність/ серйозність; 
К - художнє мислення/ реалістичне;

M - власні рішення, незалежність/ залежність від групи;

$\mathrm{H}$ - підпорядкованість правилам/ неорганізованість.

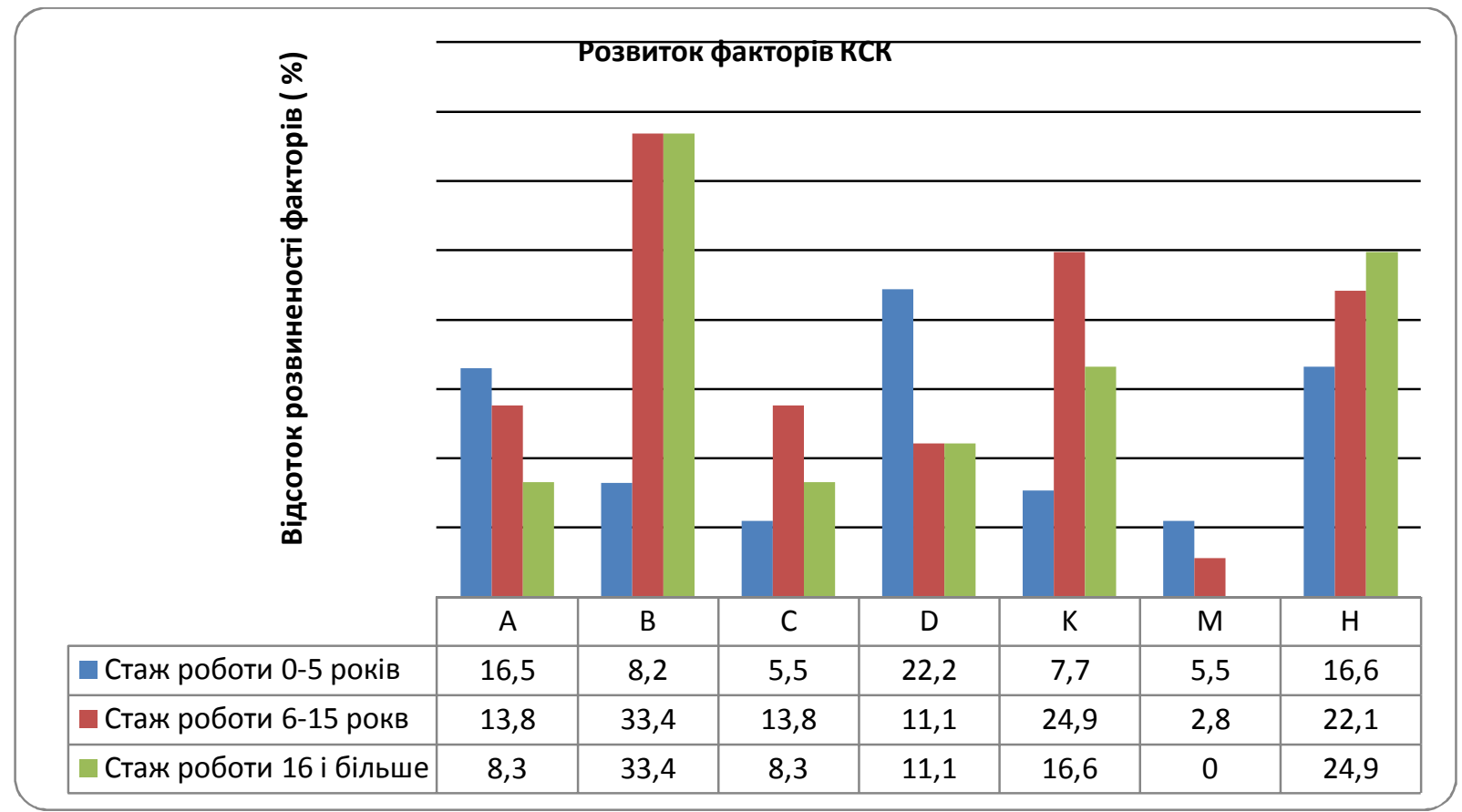

Рис. 1. Рівень розвиненості факторів комунікативної та соціальної компетентності (КСК) учителів

Результати розподілу по групах діагностики здатності до самоуправління в спілкуванні за «Методикою вивчення здатності до самоуправління в спілкуванні» представлені на рис. 2.

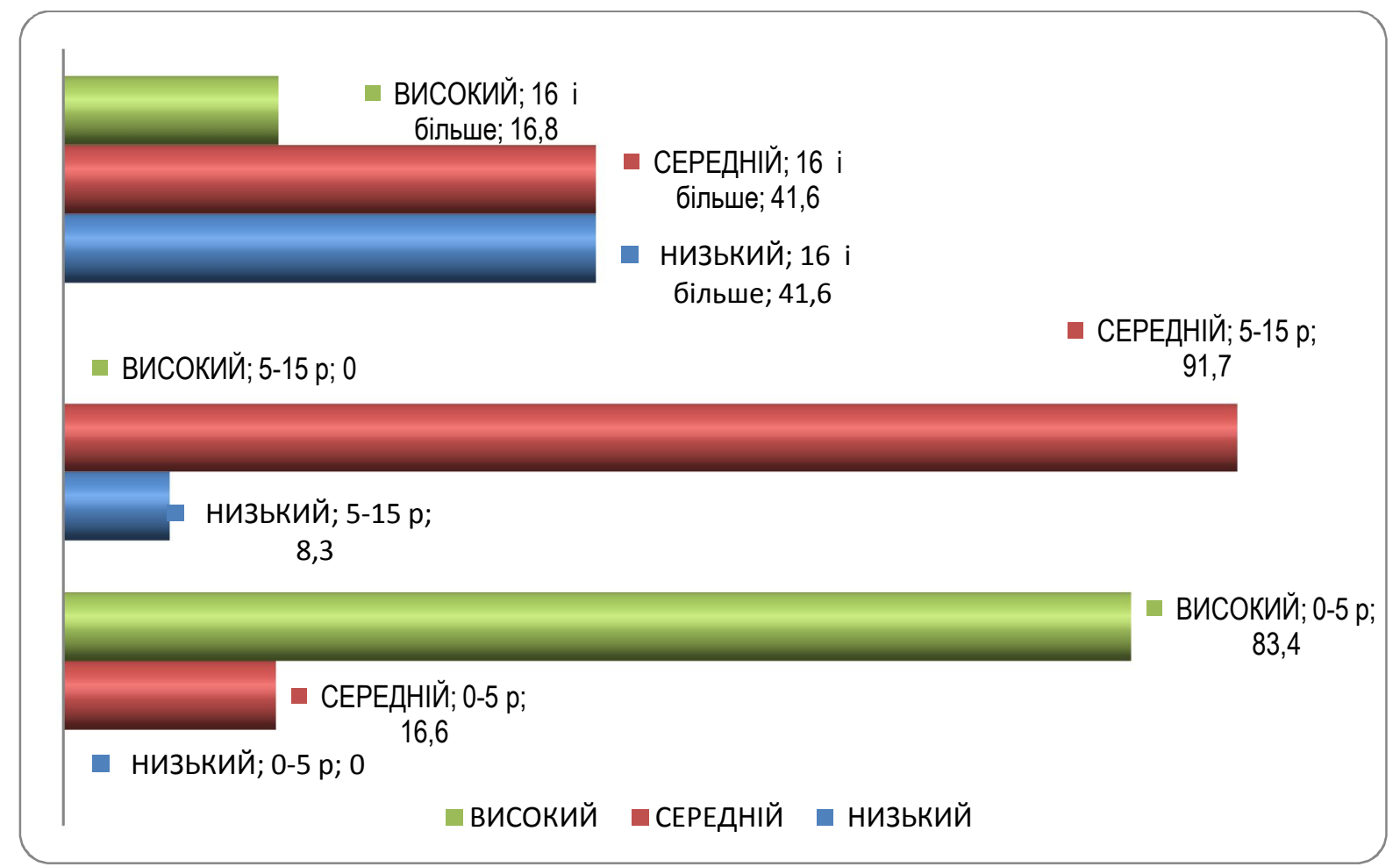

Рис. 2. Результати діагностики здатності до самоуправління вчителів у спілкуванні за «Методикою вивчення здатності до самоуправління в спілкуванні по групах за стажем 
Далі представлено результати вивчення доброзичливості вчителів за шкалою Кемпбела (рис. 3).

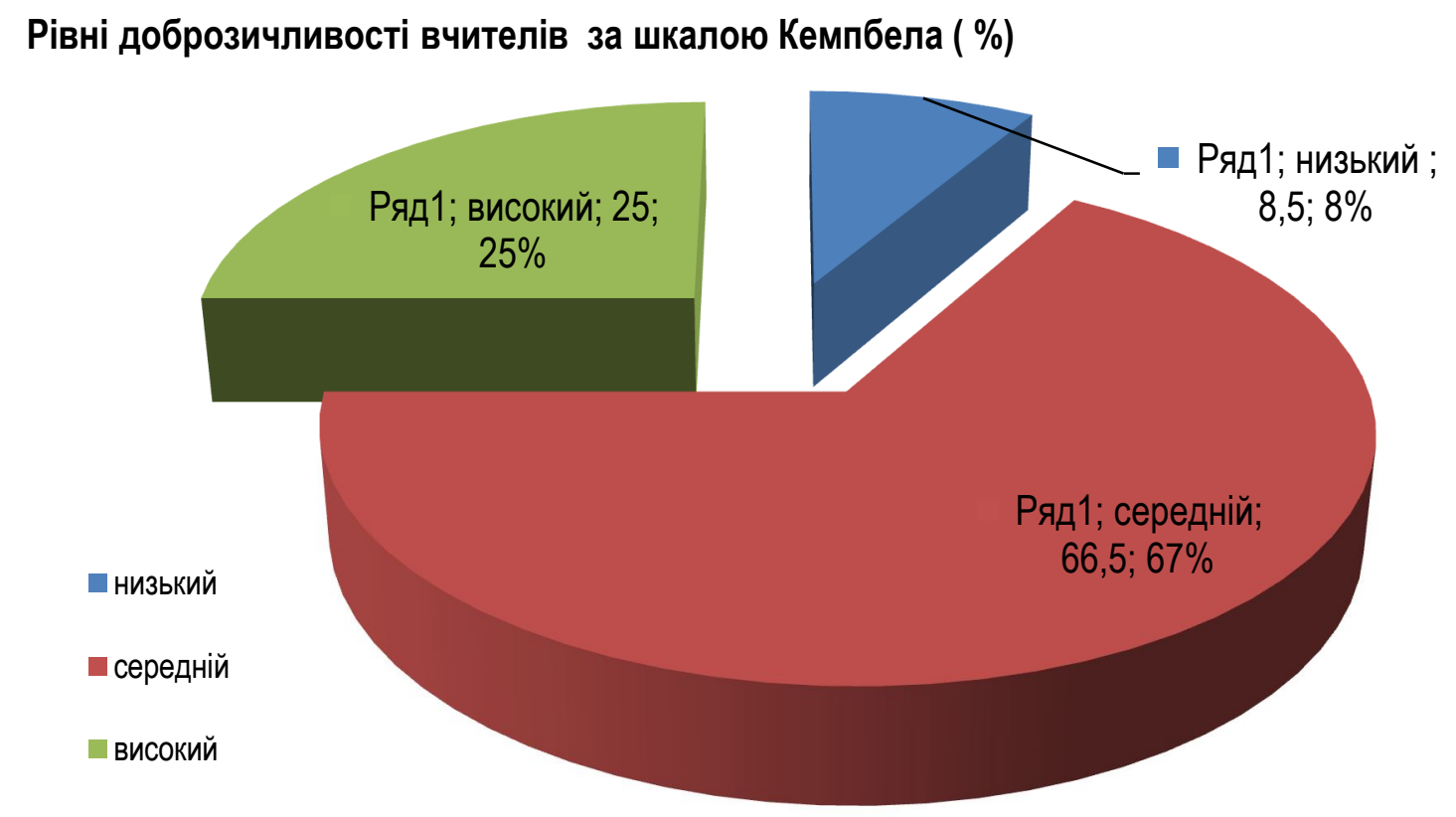

Рис. 3. Результати діагностики доброзичливості вчителів за шкалою Кемпбела

\section{IV Обговорення}

Як позначено на рис. 1, максимально високий рівень за фрактором (А) показали учителі, що працюють в ліцеї до 5 років. Найкраще розвинені педагогічні якості на високому та максимально високому рівні за фактором (В) групах досвідчених педагогів,т обто тих, хто працює в ліцеї більше 5 років. Дослідження фактору (В) свідчить, що тільки серед молодших педагогів цей відсоток становить (5,5\%), від загальної кількості опитаних в той час, як в двох інших групах відповідних показників не зафріксовано.

Отже, більш досвідчені педагоги активно проявляють інтелектуальні здібності в спілкуванні, творчо й кмітливо їх реалізують у порівнянні з молодими спеціалістами.

Також, учителі, які працюють в ліцеї від 5 до 15 років, емоційно стабільніші (за фактором С), свідомо контролюють та регулюють свою емоційну сферу. Молоді вчителі менше включають логіку в спілкуванні та відрізняються від більш досвідчених більшою неуважністю/ігноруванням по відношенню до співбесідника.

Молоді спеціалісти, а також ті вчителі, хто працює більше 16 років емоційно не стабільніші та більш вразливі.

За фактором (Д) в більшості вчителів домінують життєрадісні тенденції, високий рівень товариськості. Відповідна тенденція прослідковується і в молодих учителів, які нещодавно розпочали свою трудову діяльність в ліцеї.

Лише $(8,2 \%)$ педагогів від загальної кількості опитаних мають низький рівень показників за цим фактором. При з'ясування особливостей за фактором (К) (чутливість, художнє мислення - покладається на себе, реалістичність, раціональність) було встановлено високий та максимально рівень майже у (84 \%) респондентів.

Як бачимо, основний відсоток педагогів характеризуються як такі, що більше покладаються тільки на власні сили, реалістичні та раціональні. Педагоги групи 2 (6 - 15 років стажу) мають найвищі показники за цим фактором. 
Важливо відмітити, що в педагогічних системах іноді доводиться працювати за чіткими програмами та дидактично виправданими методичними прийомами (фактор (М) вказує саме на те. Найрезистентнішими до методичних змін $є$ педагоги, що працюють в ліцеї більше 15 років. Така тенденція, ймовірно, $€$ характеристикою залежності від виконання нормативно-регламентованих навчальних завдань і традиційності спрямування вмінь учнів. Група молодих спеціалістів (до 5 років стажу) фактором (Н) має ознаки зниженого контролю, менш усвідомлену професійну позицію. В цілому по вибірці за цим фактором більшість учителів комформніші до прийняття правил і зразків професійної поведінки.

Проаналізуємо результати діагностики здатності до самоуправління в спілкуванні за «Методикою вивчення здатності до самоуправління в спілкуванні розподілились в цілому по вибірці наступним чином: високий рівень здібності до самоуправління в спілкуванні - $(33,5 \%)$ досліджуваних, середній (50\%) осіб, та низький - у (16,7\%) осіб.

Отже, по групах за стажем, відповідно, маємо такі результати: високий рівень здатності до самоуправління демонструють $(83,4 \%)$ педагогів першої групи (до 5 років стажу). Вони мобільні та гнучкі в спілкуванні, вміють підлаштовуватися до поведінки партнера, готові до діалогу та здатні змінювати стиль спілкування в залежності від ситуації. Нажаль, з такими ознаками не заффіксовано у другій групі вчителів, та лише $(16,8 \%)$ здатні до самоуправління спілкуванням на високому рівні серед досвідчених педагогів ( стаж більше 15 років). Потреба бути в спілкуванні самим собою, проявляти залежно від ситуації спрямованість на партнера, схильність до партнерства в спілкуванні найбільш притаманна учителям групи 2 (5-15 років стажу) (майже 92\%) опитаних. Зазначимо лише, що такі показники в цілому корелюють з результатами наших попередніх методик (див. по тексту вище). Деяку ригідність моделі спілкування спостерігаємо у майже (17\%) осіб від загальної кількості опитаних педагогів групи 3 (стаж більше 16 років).

Як очевидно: низький рівень доброзичливості вчителів становить $(8,5 \%)$; середній - $(25 \%)$ вчителів; високий - (67\%) опитаних. Стосовно показника низького рівня закцентуємо, що це педагоги 2 та 3 груп, які мають стаж більше 5 років. Такий розподіл, ймовірно, $є$ переконливим свідченням засад довіри/недовіри, оскільки, на прямі запитання вчителі дали відповіді стосовно недовіри до інших людей та аргументували цей показник необхідністю обмежити себе рамками залежності від власних принципів.

\section{V Висновки}

Комунікативна культура вчителя передбачає культурологічну діяльність, яка забезпечує здатність свідомо керувати своїми емоціями, регулювати свої дії й поведінку, володіти собою, створювати позитивний емоційний настрій і сприятливий психологічний клімат. Комунікативна культура вчителя $\epsilon$ системою внутрішніх ресурсів, необхідних для ефективної педагогічної комунікації, зокрема в координатах цінностей-цілей і цінностей-мотивів, цінностей-знань, технологічних цінностей, цінностейвластивостей, цінностей-відношень. Цей феномен $є$ особистісною інтегративною характеристикою людини та має локалізацію в усіх царинах його професійної діяльності й залежить від наступних чинників: 1) зовнішніх: особливості культури спілкування в суспільстві, в освітній галузі, безпосередньо в закладі освіти та ін.; 2) внутрішніх індивідуально-психологічних: толерантності, комунікативної компетентності; 3) організаційно-професійних: стаж роботи, спеціальність, кваліфрікація та ін.. Факторами, що впливають на культуру спілкування в учителів $є$ розвинене почуття справедливості, висока сензитивність, емоційна реактивність та особливості педагогічної мотивації, які не завжди збалансовані до оптимальної моделі, отже є потреба в концептуалізації та розробці засобів оптимізації професійного педагогічного спілкування. У більшості своїй, вчителі ліцею готові до самовдосконалення, підвищення свого рівня педагогічної культури.

\section{Бібліографрічні посилання}
освіти
України
на період
2015-2025 pp.
URL: http://www.irf.ua/knowledgebase/news/koncepciya_rozvytku_osvity_na_period_20152025rr/ (дата звернення 04.03.2019).
[2] Чмут Т. К. Культура спілкування. Хмельницький : «ХІРУП», 1999. 358 с.
[3] Кан-Калик В. А. Учителю о педагогическом общении. М. : Просвещение, 1987. 190 c.
[4] Хомич Л. О. Професійно-педагогічна підготовка вчителя початкових класів. К. : Магістр-S, 1991. 200 с. 
[5] Селевко Г. К. Энциклопедия образовательных технологий: в 2 т. Т. 1. М.: НИИ школьных технологий, 2006. С. 21.

[6] Бондарчук О. І. Психологічна компетентність фахівця: зміст та основні підходи / Наук. вісн. Миколаїв. держ. ун-ту ім. В. О.Сухомлинського : Зб. наук. пр.; Сер. «Психологічні науки» ; за ред. С. Д. Максименка, Н. О. Євдокимової. Т. 2. Вип. 8. Миколаїв: МНУ імені В.О. Сухомлинського, 2012. С. 30-36.

[7] Лукьянова М. И. Психолого-педагогическая компетентность учителя : Диагностика и развитие. М. : Сфера, 2004. $144 \mathrm{c}$.

\section{References}

[1] Kontseptsiia rozvytku osvity Ukrainy na period 2015-2025 rr. URL: http://www.irf.ua/ knowledgebase/ news/ koncepciya_ rozvytku_osvity_na_period_20152025rrl (accessed 04.03.2019). [in Ukrainian]

[2] Chmut, T. K. (1999). Kultura spilkuvannia. «KhIRUP», Khmelnytskyi, Ukraine, 358. [in Ukrainian]

[3] Kan-Kalyk, V. A. (1987). Uchyteliu o pedahohycheskom obshchenyy. Prosveshchenye, Moscow, USSR, 190. [in Russian]

[4] Khomych, L. O. (1991). Profesiino-pedahohichna pidhotovka vchytelia pochatkovykh klasiv. Mahistr-S, Kyiv, Ukraine, 200. [in Ukrainian]

[5] Selevko, H. K. (2006). Entsyklopedyia obrazovatelnykh tekhnolohyi: v 2 t. T. 1. NYY shkolnykh tekhnolohyi, Moscow, Russia, p. 21. [in Russian]

[6] Bondarchuk, O. I. (2012). Psykholohichna kompetentnist fakhivtsia: zmist ta osnovni pidkhody. Nauk. visn. Mykolaiv. derzh. un-tu im. V. O.Sukhomlynskoho : Zb. nauk. pr.; Ser. «Psykholohichni nauky»; za red. S. D. Maksymenka, N. O. Yevdokymovoi. T. 2. Vyp. 8. Mykolaiv: MNU imeni V.O. Sukhomlynskoho, 30-36. [in Ukrainian]

[7] Lukianova, M. Y. (2004). Psykholoho-pedahohycheskaia kompetentnost uchytelia : Dyahnostyka y razvytye. Sfera, Moscow, Russia, 144 p. [in Russian]

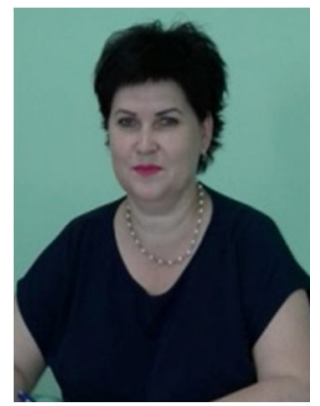

Давидова Оксана Володимирівна.

кандидат психологічних наук, асистент кафедри психології, педагогіки та філософіії Кременчуцький національний університет імені Михайла Остроградського, вул. Першотравнева, 20, м. Кременчук Полтавської обл., Україна, 39600. Тел. 067-90-100-46. E-mail: 71kseniya@gmail.com

\section{Davydova Oksana Volodymyrivna.}

Candidate of Psychological Sciences, assistant the department of psychology, pedagogy and philosophy Kremenchuk Mykhailo Ostrohradskyi National University,

vul. Pershotravneva, 20, Kremenchuk, Poltava Region, Ukraine, 39600.

Phone: 067-90-100-46. E-mail: 71kseniya@gmail.com

ORCID: orcid.org/0000-0003-3553-7118

Citation (APA):

Davydova, O. (2019). Psychological peculiarities of the communicative culture of the teacher. Engineering and Educational Technologies, 7 (2), 190-197. doi: https://doi.org/10.30929/2307-9770.2019.07.02.19

Цитування (ДСТУ 8302:2015):

Давидова О. В. Психологічні особливості комунікативної культури вчителя / Інженерні та освітні технології. 2019. Т. 7. № 2. С. 190-197. doi: https://doi.org/10.30929/2307-9770.2019.07.02.19

Обсяг статmі: $\quad$ сторінок - 8 ; умовних друк. аркушів - 1,159. 